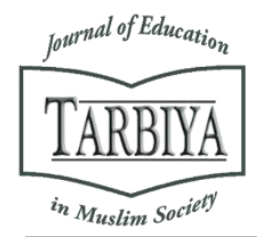

Available online at TARBIYA: Journal of Education in Muslim Society Website:

http://journal.uinjkt.ac.id/index.php/tarbiya

TARBIYA: Journal of Education in Muslim Society, 3(2), 2016, 242-251

\title{
HUMAN RESOURCE MANAGEMENT FOR EARLY CHILDHOOD EDUCATION
}

\author{
Siti Zaenab \\ Gde Pudja Mataram State Hindu Collage (STAHN), Indonesia \\ E-mail: sita.zaenab99@gmail.com
}

Received: $15^{\text {th }}$ September 2016; Revised: $13^{\text {th }}$ November 2016; Accepted: $24^{\text {th }}$ December 2016

\section{Abstract}

This study is aimed to describe the human resources in early childhood education which become basic needs for early childhood institutions that is in line with the vision to reach Indonesia Gold 2045. The focus of this research, can be divided into several sub-focuses; including the planning of recruitment, selection, assignment, development, and evaluation. The method used is phenomenological qualitative research with multi-case studies. The validity was done through applying credibility, dependibility, and confirmability. Data analysis technique conducted in each of the three cases using two approaches, namely (1) the analysis of individual cases and (b) cross-case analysis. The results of this study can be presented as follows: (a) human resources in early childhood education needs to be developed, so the goals can be successfully obtained. (b) The principal, teachers, and stakeholders need to be more progressive at the time of selection of qualified early childhood teachers S1, (c) to produce teachers and administrative staffs who have educational qualifications for early childhood education. The educational criteria required is S1 PG PAUD.

Keywords: human resources management; early childhood; Mataram

\section{Abstrak}

Penelitian ini bertujuan untuk menggambarkan mengenai sumber daya manusia pada pendidikan anak usia dini yang menjadi kebutuhan dasar bagi lembaga pendidikan usia dini yang sejalan dengan visi untuk mencapai Indonesia Gold 2045. Fokus penelitian ini dapat dibagi ke dalam beberapa subfokus; meliputi perencanaan penerimaan, pemilihan, penugasan, pengembangan, dan evaluasi. Merode yang digunakan adalah penelitian kualitatif fenomenologi dengan studi multikasus. Validitas dilakukan dengan menerapkan kredibilitas, reliabilitas, dan konfirmabilitas. Teknik analisis data dilakuakn pada setiap tiga kasus menggunakan dua pendekatan, yakni (1)Analisis kasus individu dan (2)analisis lintas kasus. Hasil Penelitian ini disajikan sebagai berikut: (a) sumber daya manusia pada pendidikan usia dini perlu dikembangkan, sehingga tujuan dapat sukses dicapai. (b) Kepala sekolah, para guru, dan pemangku kepentingan perlu lebih progresif saat memilih guru sekolah usia dini yang berkualifikasi S1 (c) untuk menghasilkan guru dan pegawai administrasi yang berkualifikasi pendidikan usia dini. Kriteria pendidikan yang dibutuhkan adalah S1 PG PAUD.

Kata kunci: pengelolaan sumber daya manusia; usia dini; Mataram

How to Cite : Zaenab, S. (2016). Human Resource Management for Early Childhood Education. TARBIYA: Journal of Education in Muslim Society, 3(2), 242-251. doi:10.15408/tjems.v3i2.4063.

Permalink/DOI: http://dx.doi.org/10.15408/tjems.v3i2.4063 


\section{Introduction}

West Nusa Tenggara province is the most populated-Muslim province in which most of the people are Sasaknese. In West Nusa Tenggara, the majority of the population is Muslim (96\%). West Nusa Tenggara is wellknown as the City of Thousand Mosques. The slogan of this city is "Worship" as "Religious State". Therefore, the government began to take into consideration to all areas of education, especially in early childhood. This effort is a step forward to improve the quality of human resources in West Nusa Tenggara aimed to empower the potential human resource. To build the human resource that has character, knowledge and skills required, it needs guidance from an early age. Early childhood education is the beginning step to form human intelligent, healthy, noble character, as well as having high intelligence.

The tendency of the proliferation of early childhood education provision to the outlying rural areas in West Nusa Tenggara province and the City of Thousand Mosques especially without accompanied on the availability of facilities and infrastructure, as well as educators and professional educators will only creates new problems for education. Early childhood education that does not be managed carefully, will likely to build the foundations of "defects" that the impact will be devastating for education on it. There is a saying that states that "studying by the youth is like carving on the stone, and studying by the olds is carving on paper." Early childhood world is the real world that brings the child toward a solid foundation. So is education today has the power to make changes. The changes will bring the Early Childhood educators to create some innovation of teaching techniques such as learning through games that shapes the students into smart and cheerful. It can be evaluated accurately and completely to achieve objectives in a productive, high quality and efficient way (Zaenab, 2008).

In accordance with Government Regulation No. 19 Year 2005 on National Education Standards teachers should meet 4 (four) competencies that must be mastered. Those are personal, pedagogical, social, and professional competences. Furthermore, in the Minister of National Education of the Republic of Indonesia Number 58 Year 2009 on early childhood education standard is the standard of teachers and education personnel. Standards for early childhood education includes four groups: (1) the standard level of achievement development, (2) the standard of teachers, (3) the content standards, processes and assessment, and (4) the standard of facilities and infrastructure managers and finance (Directorate Early Childhood Eduaction, 2010; 1).

Related to Government Regulation No. 19 Year 2005 on standard Pedidikan into Permendiknas 58 Year 2009 on Early Childhood Education Standards. It reaffirms the division of early childhood education into three: early childhood education, formal consisting of Kindergarten (Raudhatul Athfal) or early childhood education, non-formal consisting of "Playgroup", Day Care, or other forms equivalent and education informal early childhood held in the family. One type of early childhood education, informally known is homeschooling (Arifin, 2011 I. 2-3).

Based on the surveys in $17^{\text {th }}$ September 2015, the face of education in Indonesia in general and the city of Thousand Mosque in particular is one thing to note why there is a problem occurs, because the educators in early childhood education is a voluntary professional (volunteer). The first voluntary educators is based on willingness and passion to teach without amenities allowances received by a teacher in general such as certification allowances 
for certified teachers, educators professional allowances, transport allowances and functional benefits. The second volunteer is willing to sacrifice the time to serve the community that provides education in early childhood.

Soetopo (2007) states that the role of teachers in the construction appeared to have caused serious imbalances, setting priorities and targets the wrong direction, the low quality of human resources, as well as low participation and community support. The direct effect is the lack of legitimacy and the degree of implementation of the policies of the central government and regional's autonomy designed to overcome these problems. Departing from these issues, then it should be, that in order to implement regional autonomy in a real sense and in order to answer the challenges of the problems in the present and future, these several items are necessary (1) to discover the identity of teachers and education personnel in each autonomous region, (2) evaluation of the readiness of human resources in the autonomous region of candidates educator formerly centrally managed now be decentralized. Quality of teachers will affect the quality of the nation. Chilhood development is a golden period (golden age) needed to be inprinted by qualified educators and professionals. Approximately, 50\% of adults intelligence formed in childhood, $30 \%$ was formed after the age of 8 years and the remaining $20 \%$, after the second decade. If this situation happens, then education in the form of playgroups and schools is absolutely necessary. That what makes researchers interested in the phenomenon that is themed "Human Resource Management in Early Childhood Education in the West Nusa Tenggara" (multi case study on three early childhood in the city of Thousand Mosques).

\section{Method}

This research uses descriptive phenomenological qualitative approach with case study design. A qualitative approach, which is to say, an approach that oriented on the symptoms that are natural and fundamental Nasution, (1998:67). A qualitative approach was chosen because the object of this research is a process or activity or actions (some) people, which is about the management of human resources in early childhood education, the research object in a state of nature (natural), and the data disclosed not in the form of figures, but the form of words, sentences, paragraphs and documents. Miles \& Huberman (1992:45). In order to get a complete and detailed data about the studied subjects, related to the focus and purpose of the study, exploration, either completely or in a focused way.

Patton (2006: 5) states that qualitative methods in particular produced a wealth of detailed data on many people and a lot of cases. Qualitative data provide depth and detail by quoting directly and accurately descriptive conformed to the programs, events, people, interactions, and observed behaviors, in line opinion (Pidarta, 2006: 14). This research was conducted in Mataram, City of a Thousand Mosques. This location was chosen, because it is unique in terms of their teachers' willingness who would like to teach without given salary or honorarium.

Bogdan \& Biklen: 1992, in Arifin: 1995, to obtain the data in a holistic and integrative, and with regard to the relevance of the data with the focus and purpose. The data were collected through (1) in-depth interviews (depth interview) (2) participants observation (participant obsevation), and (3) study the documentation. Three techniques can be said to represent the three basic techniques in qualitative research agreed by most authors. 
Miles and Huberman (1984), who started or concurrent with data collection and after data collection. Analyzing data is carried out simultaneously with the data collection activities, including: (1) the establishment of a research focus is fixed as planned or need to be amended; (2) the preparation of the findings; (3) creation of the next data collection plan based on the findings of previous data collection; (4) development of analytical questions for the next data collection; and (5) determining the next data collection suggestions.

\section{Results and Discussion}

The findings show that there is a standard process for recruiting the appropriate human resources, with the aim that educators have good qualifications and good quality standards. Improving the quality of teachers through further study or training is a step forward for those who have limited knowledge. For further studies, this research is addressed to be in the allotment for educators who have the willingness to special school. For educators, that the limitations of the study costs. It is based formulations propositions derived from research findings from evaluating the case, which is to achieve the stated goals and the necessary planning of the recruitment process needs human resources with competence in the field based on the principle of the right man on the right place.

From the opinions can be formulated that the recruitment process should be considered human resource planning. In terms of determining the needs ranging from recruitment, selection, placement, training, and evaluation, including consideration of competency or qualifications necessary. Technical question is part of external staffing's fulfillment of placement outside the organization, if a shortage of teachers to fill the vacancy gap specialization or certain important positions.

\section{Recruitment Educators In Early Childhood}

Planning recruitment of human resources is defined as planned activities programs related to efforts to help achieve the goals set by the management of human resources. According to Barry (1996), John and Pauline (1994) states that the planning educator (HR) is a way to establish employment purposes (HR) for a certain period both in quality and quantity for certain ways. HR Procurement is an attempt to simplify the number and types of individuals that are appropriate to the needs of human resources in an organization of institutions. Randall (1999) further stated that HR planning has functions related to the problem of determining the needs of recruitment, selection, and placement.

From some of the recruitment process, there are some considerations related to human resources planning, especially in terms of determining the needs ranging from recruitment, selection, placement, training, and evaluation. Also, the consideration of competency or qualifications necessary technical question here is part of external staffing is meeting the needs of the placement of outside the organization, if a shortage of teachers to fill the vacancy gap specialization or certain key positions.

There is a well-regulated mechanism in the determination of the alleged (forecasting) needs. According to Pidarta (2009) suggested that the recruitment of prospective teachers is an activity search of potential candidates with a view to placing them according to their position in early childhood school. The purpose of a recruitment program educator is to provide or attract the best people and provide the widest opportunity for people to apply their educational qualifications with the experience possessed. It also to facilitate the administrator as a team 
member recruitment, to find candidates quality and candidates stand.

Torrington and Huat (1998: 163) stated that "recruitment is one of the basic functions of human resource manager where by the most suitable person is thought to fill a job vacancy" which translates into: "the recruitment is one of the basic functions of management human resources where most of the people who deserve fill job vacancies". In line with the opinion of Hasibuan (2001) suggested that recruitment is generally done when organizations need a group of prospective educators with certain criteria, particularly candidates for executive educators (operative), while special recruitment used mainly for power, leadership (executive) or specialized experts.

The above opinion is supported by the statement of Soetopo (2007) that accountable human resource management is the ability of planning, implementation and outcome evaluation in which stekholders act as a user. The management and the mechanism on the institutions of early childhood education has been formed, but the changes in the renewal of human resources management for coming years need to be functioned. PAUD continuesly applying management concepts, planning good recruitment, but in principle agree with Castallo (1992) in Kusmintardjo (2002), that there are two reasons of recruitment process: first educator profession is a job or position that requires expertise, knowledge, responsibility, loyalty to the professional performance of teachers and actions of the profession itself. Definition of unity using the word because of his knowledge, able to describe their inner potential educators in early childhood must be respected. The second definition uses the word character, which means their obligations in responding requests from outside parties respect the existence of the early childhood teachers.
Related to the recruitment of human resources, the place where the research conducted agreed that the first candidate in the early childhood educators should be produced based on the expectations, needs (satisfying) professions, professional, Second, competence in the field of early childhood education is recognized by the foundation and staholders. Third, the willingness to devote themselves as noble ideals in contributing energy and thoughts is the main indicator in educating the children of the nation.

Castallo (1992) distinguishes recruitment and training into two; accountability results (outputs) and impact (outcomes). Accountability results is the duty of the institution as the executor, while the impact is the obligation of the institution as a policy-making refers to the opinion Gasskov (2000). To overcome the impact of the body's quality of early childhood education to be qualified, the duty and responsibility of government as decision-making on procurement of power ECCE remains the first order, However, Gasskov (2000) also says that the frequent confusion between the limits of the authority, obligation makers and implementing agencies that exist cause confusion to the institutions, such as in the provision of quality for early childhood educators with the hope of improving HRM.

Planning the recruitment of educators in early childhood, including five sub-themes, namely the quality of teachers is planned, recruitment, selection, placement, training, and evaluation of early childhood teachers work. In this recruitment process there are five propositions as early childhood educators should ideally have: (1) a personality that could be an example for student participants, (2) competence in the field of science, there are three: teaching methods, theory and practice of early childhood education. (3) skills ideally Educator par with graduates of S1 and S1 PG ECD similar 
minimum at a more comprehensive level, to a higher level than a high school graduate or equivalent. (4) the quality of teachers internally measured based on experience, while, externally measured by the satisfaction of users or high demand for early childhood education graduates who enter primary school.

\section{According to Holmens Group (1986),} competent educators must meet three aspects, namely the control of teaching materials, master the science of teaching, and teaching experience. Fathoni (2006) states that the provision of human resources is the provision of labor is an effort to obtain and collect, as well as providing educators who have qualities that can work efficiently. Provision of educators is a crucial stage in the life of educational institutions, especially several less points there are educators who have personality trait is less support for the implementation of the educational institutions.

\section{Selection Educators In Early Childhood}

Selection S1 PAUD program was compiled using a competency-based approach, although the foundation managers realize that the work program is less supported. Achievement of competence of graduates as already formulated. Selection is part of employee procurement program, where the selection was implemented to meet the needs of employees based on the number and arrangement of the rank that exist in a school. Selection of early childhood teachers is a means for institutional foundations to obtain highly competent teachers, qualified, and committed to the foundation. The selection process is central to the success of human resource management and the foundation. Failure means the failure of an organization to achieve its objectives (John Ivancevich: 2015).

\section{Zaenab (2012: 20) "Selection is an} activity that is carried out to select candidates for early childhood teachers who are considered most appropriate to teach in early childhood and should have the potential development of the child in order to teach well." The selection is also a process for selecting early childhood teachers and most qualified in accordance with the conditions set by the foundation, to fill the kind of jobs that exist, or to be held by a foundation. In addition, the selection can also be interpreted as a means or a tool to select individuals who have certain qualifications to teach in early childhood that there was recently opened. According UUSPN No. 20 of 2003 states that educators are community members who are devoted and raised to support education.

The selection process is the steps that must be passed by the applicants until obtaining a decision whether he is accepted or rejected as a new early childhood teachers. To carry out the selection requires the instrument or tool in the selection process: form fields, administrative requirements, testing / tests, interviews, physical and mental health, reference.

There are two forms of information to be achieved from the selection process, such as the information about the school, educators, and available teaching process. Information about the applicant is required by the school to determine whether the applicant meets the expectations of the school, while the information about the school required that applicants be able to measure the competence themselves.

Before prospective educators are selected in accordance with the method to be used, preferably prospective educators are given the form fields (sheet list of applicants), which contains questions to be filled. Questions provided to educator candidates should be clear and structured to enable them to answer the questions fluently. The purpose of the filing is to record the following matters: (1) Provide a general description of the person of the applicant; (2) get an impression of the character and the personality traits of the applicant; (3) 
gain certainty whether the prospective educators meet the criteria required and have the capacity; (4) to determine the potential educators nominated and which ones should be called to follow the next stage of selection.

Therefore, in outline, the selection of educators conducted in early childhood education with a view to obtain firmness of skills, personality, habits, and other data and information necessary to get educators are efficient and effective. To assure the accomplishment of the expected need, the use of specific selection method is needed. It includes: the selection of administrative requirements, general knowledge, psychology, interviews and references.

\section{Placement Educators in Early Childhood}

From place of the research the placement of educator candidates is not so difficult, because the principal can see firsthand the ability of educators who have been recruited by the quality and the main goal. To improve the quality of teachers in institutions of early childhood education, the process of recruitment, selection and placement based on the results of previous evaluations and input from various parties, such as principals, teachers, the stakeholders, are already eligible who have been determined. However, there are differences in processes and evaluation targets.

First, early childhood institutions should not accept educators instead of S1 PG PAUD graduates and high school graduates. This indicator declines in quality of education, except for graduates of high school as a nanny. Second, early childhood institutions also set the two goals, but the new program to develop the quality with $S 1$ graduates from various disciplines. With the S1 employs similar and yet S1 PG PAUD in giving a chance to yet $S 1$ to continue the study in order to improve the quality as an indicator of other disciplines.
Clark, (2002) in Hasan (2002) states that the competency-based education, educational institutions should establish regular contact with the stakeholders.

Development patterns educators with affective aspects (attitudes and behaviors) educators is more difficult than forming academic skills for the limited range of material and systematics assessmennt, Affective aspects may include interests, attitudes, application of the values (values), appreciation, and adjustment. The interest alone could be reexamined starting from awareness to behavior towards a phenomenon that exists, Bafadal (2004). The tendency PGPAUD graduates qualified for the phenomenon needs to be studied. Development patterns educators with affective aspects (attitudes and behaviors) educators more difficult than forming konpetensi academic and skills for the limited range of material and systematics pengukuranya. Affective aspects may include interests, attitudes, application of the values (values), appreciation, and adjustment. The interest alone could diuriakan again starting from awareness to behavior towards a phenomenon that exists Bafadal (2004). The tendency PGPAUD graduates qualified for the phenomenon needs to be studied.

The policy and early childhood teacher professional development must be sustainable, with a series of specific activities. Begin with the preparation of prospective teachers, recruitment, placement, assignment, professional development and career, to be a true professional teachers, who undergo continuous professionalization. Referring to this reasoning, the true professional teacher is a teacher carrying out their duties and functions are autonomous, master competencies in a comprehensive and high intellectual power. Professional development of teachers is sometimes preceded by the performance appraisal and competency 
tests. To determine the performance and competence of teachers conducted performance appraisal and competency tests. It can be formulated on the basis of profiles and maps the performance and competence. Real condition that is the one basis to increase the competence of teachers.

Therefore, the relevant issues to the future management of teachers require the formulation of systemic main supply systems, recruitment, appointment and placement, distribution systems, certification, qualification, performance appraisals, competency testing, appreciation and protection, welfare, career development, continuing professional development, supervision of professional ethics, as well as the management of teachers in special areas. It can be seen that being a teacher is a noble profession, but to become professional completing education in college and attend trainings were held later. To be a teacher is not as easy as turning the palm of the hand. If in the future someone becomes a professional teacher, he should not forget about the rights and responsibilities of teachers to participate in various policies in the promotion and development of teachers organized by the Ministry of National Education.

\section{Evaluation of Human Resources}

Evaluation on PAUD involves principals, teachers, parents as well as foundations and stakeholders, both formally and informally. Evaluation targets include the organizers of the program and the quality of graduates. Empowering educators and self-evaluation were done through the establishment of selfevaluation team level of early childhood schools and foundations as well as through the senior teachers. The participation of parents in the process of self-evaluation is formally made by filling a questionnaire evaluation of the teaching and learning process at the end of each year, and informally through periodic meetings between principals and parents with the board of trustees.

PAUD also conduct periodic self-evaluation. Although it is already good, it still less structured than management. To support the implementation of self-evaluation of the sub-part education has started to collect information about the competency of the PAUD. PAUD has pioneered formal evaluation process involving principals, and teachers, though not intensively conducted. The results sent to the foundation managers, and study programs. The results of these evaluations become inputs and develop a work program next year. Using the findings of an evaluation of the PAUD manager in accordance with the opinion of Jalal and Suparno (2001) that the accountability of early childhood education is also evaluated by the conformity between the stated objectives and the results achieved and expected by society.

The conclusions from the findings are that taking into consideration the human resources to manage PAUD is still limited. Community members or organizations that manage early childhood should be stirred and do everything possible to improve the competence of teachers and to meet the minimum standards of competence specified. The recruitment process of teachers and early childhood use different references (references), either in the form of legislation or writings that expressed by experts and practitioners. Considering the standard of early childhood education as defined by National Education Minister Regulation No. 58 Year 2009 is not equipped with further descriptions (derivative) in the form of guidelines / reference implementation educators. The development of guidelines, the reference to the standard of educators and education personnel, early childhood education is seen important to do, so it can be used by those who work in the field of early childhood education, both at central and regional levels. 


\section{Conclusion}

The results of this research indicate that there is no standard process for recruiting the appropriate human resources, with the aim that educators have good qualifications and good quality standards. Improving the quality of teachers through further study or training is a step forward for those who have limited knowledge and for more studies will further education in the allotment to educators who have the willingness to special schools for educators that the limitations of the study costs.

It is based formulations proposition research findings obtained from the study site, which is to achieve its intended purpose and competence in the field in accordance with the principle of the right man on the right place. Planning of the recruitment process human resource needs that have educators in early childhood education is needed by the foundation with the following criteria: have a diploma S1 early childhood, experienced in parenting students, mastery of the concept of early childhood, producing educators who meet demand, especially for managers in accordance with the needs in the organization of early childhood. For selection purposes striking educators in early childhood must have quality educators who graduate PGPAUD S1, so that the future can improve the quality of prospective educators.

the institution need to evaluate the performance of educators on the recruitment process until the evaluation of early childhood educators do programmatically by a team or a specialized institution with standard parameters or indicators. To measure the success of the targets of each indicator of recruitment, selection, placement, training, and evaluation on the need for educators who have qualified PGPAUD S1. Evaluation for educators will go well if supported by: the foundation, principals, educators, and stakeholders from the various elements present. Evaluation of the placement process and evaluation conducted by a team of educators and principals, formally and informally.

Based on the findings and conclusions of research, it is recommended to: (1) Government, The Ministry of Education and Culture, in order to respond positively to the results of research and to strengthen human resource improvement of data on early childhood; (2) the chairperson of early childhood education, the results of this study can be implemented as an evaluation, as well it share innovations that have been made in the field of human resource management in order to improve the quality of this early childhood; (3) to the early childhood educator, for comparison and improvement of human resource management; and (4) other researchers, could follow up this research by looking at the context and a different focus, or research focus partially, such as the development of the child or see the focus in the field of management, so that research results can then enrich the academic discourse and practice on the development of early childhood education in the homeland.

\section{References}

Arifin. I. 2011. Kepemimpinan HIMPAUDNI studi kasus di Kota Malang. Seri Penelitian Kualitatif. Aditya Media Publising Malang.

Bafadal, I. 2004. Dasar-Dasar Manajemen dan Supervisi Taman Kanak-Kanak. Penerbit Bumi Aksara Jakarta.

Bogdan, R.C., \& Biklen, S.K. 1998. Qualitave Research. Needham Height, MA: Alln \& Bacon. 
Castallo, R. T., Matthew R. Fletcher,A. D. Rossetti, R. W. Sekowski. 1992. School Personal Administrastion. Allyn and Bacon. Boston London Toronto Sydney Tokyo Singapore.

Fathoni, 2006. Manajemen Sumber Daya Manusia. Pustakan Jakarta: Pub.

Gasskov, V, 2000. Managing Vocational Training Sistem. Geneva. ILO

John, W. dan Pauline, D 1994. Managing The Human Resources. Terjemahan London: Prentice Hall Int.

Miles, M. B., \& Huberman, A.M. Tanpa Tahun. Analisis Data Kualitatif. Alih bahasa Rohidi, T. R. 1992. Jakarta: UI Press.

Nasution. 2001. Metode Research (Penelitian Ilmiah). Jakarta; Bumi Aksara.

Patton, M.Q 1990. Qualitative Evaluation Research Methods. Secon edition,Newbury Park :SAGE publication Inc.

Peraturan Presiden. RI. Nomor 66 tahun 2010, tentang perubahan atas peraturan pemerintah nomor 17 tahun 2010 tentang pengelolaan dan penyelenggaraan pendidikan.

Peraturan Menteri Pendidikan Nasional Republik Indonesia No 58 Tahun 2009 tentang Standar Pendidikan Anak Usia Dini. 2009 Bandung Penerbit Citra Umbara Indonesia.

Peraturan Pemerintah RI No. 19 Tahun 2005.2006. Tentang tandar Nasional Pendidikan. Jakarta: Sinar Grafika.

Pidarta, M. 2006. Analisa Data Penelitianpenelitian Kualitatif dan Artikel. Konsep dan Contoh. Penerbit Unesa University Press Anggota IKAPI. Surabaya.
Randall, S. S \& Susan E. Jakson 1999. Manajemen Sumber Daya Manusia. Penerbit Airlangga Jakarta. Edisi ke Enam jilid 2. New York University.

Soetopo ,2007. Peran LPTK dalam menyiapkan tenaga kependidikan yang berkualitas. Jurnal Manajemen Pendidikan Volume, 20 Nomor 1 Maret 2007. ISSN 08521921.

Suparno, P. 2001 Teori Intelegensi Ganda dan Aplikasi Di Sekolah. Kanisius Yogyakarta.

Torrington. D. \& Huat Tan Chec. 1998. Human Resource Management for Southeast Asia. New Jersey. Englerwood cliff.

Undang-undang No 20 Tahun 2003. Tentang Sistem Pendidikan Nasional. Bandung: Citra Umbara.

Undang-Undang Nomor 23 Tahun 2002, Tentang Perlindungan Anak.

Undang-Undang RI Nomor 20 Tahun 2003. Tentang Sistem Pendidikan Nasional.

Whether, W. B. \& Davis, K. 2008. Personalia Management and Human Resource. New York: Mc. Graw Hill BC.

Zaenab. 2008. Manajemen Pendidikan Anak usia Dini Kelompok Bermain (PAUD Asri Tunggal) Kota Mataram, Tesis tidak dipublikasikan Universitas Negeri Surabaya. (UNESA).

Zaenab, S. 2012. Manajemen Sumber Daya Manusia pada Tiga PAUD di Kota Mataram (studi multi kasus di tiga PAUD Rinjani 01, 02, dan 03 di Kota Mataram), Disertasi tidak di publikasikan Universitas Negeri Malang (UM). 